Research Article

\title{
GERMINATION AND SEED VIGOUR OF INDIGENOUS BEAN (Phaseolus vulgaris) GENOTYPE IN NEPAL
}

\author{
Anupam Uprety ${ }^{1}$, Bhishma Raj Dahal ${ }^{2 *}$ and Bishal Shrestha ${ }^{3}$ \\ ${ }^{1}$ Institure of Agriculture and Animal science, Tribhuvan University, Kritipur, Kathmandu \\ ${ }^{2}$ Faculty of Agriculture, Agriculture and Forestry University, Rampur, Chitwan \\ ${ }^{3}$ Principal, College of Natural Resource Management, Bardibas, Nepal,
}

\begin{abstract}
Bean is an important vegetable crop of Nepal but farmers of Jumla district of Nepal are experiencing low productivity, probably due to poor germination. Keeping these points in view, a study was conducted to determine the germination and seed vigour of various indigenous beans genotype of Jumla district during February to March, 2018. The promising lines of Jumli beans namely KBL-3, KBL-2, PB0002, PB0001, KBL-1 and farm saved KBL-3 were used under study. The experiment was laid in completely randomized design (CRD) with four replications and six treatments namely $T_{1}=$ $\mathrm{KBL}-3, \mathrm{~T}_{2}=\mathrm{KBL}-2, \mathrm{~T}_{3}=\mathrm{PB} 0002, \mathrm{~T}_{4}=\mathrm{PB} 0001, \mathrm{~T}_{5}=\mathrm{KBL}-1$ and $\mathrm{T}_{6}=$ Farm-saved KBL-3. Significant differences were observed in germination percentage, speed of germination, seed vigourindex and true leaf emergence among different lines of Jumli beans.The highest germination percentage (96\%), seed vigour index (1367) and speed of germination (1.763) was found in the variety of KBL-3 whereas the lowest germination percentage $(69 \%)$, seed vigour index (947) and speed of germination (0.968) were found in the variety of KBL-1. Days to true leaf emergence was found shortest in the KBL-3 (23.50) and longest in the farm saved KBL-3 (30.25). KBL-3 pureline of Jumli bean was found to be highly responsive to seed germination and vigour characteristics. Thus, it would be better to suggest the indigenous bean growing farmers of Jumla district to cultivate KBL-3 for better germination and seed vigour.
\end{abstract}

Keywords: Seed germination, Germination percentage, Vigour index, Pure lines

\section{INTRODUCTION}

Bean (Phaseolus vulgaris, Fabaceae) is an indigenous pulse and a cash crop of Jumla and Karnali Zone; mostly cultivated (in terms of area) after rice, maize, wheat, barley and millet (Bhujel et al., 2012). Local landraces of beans consist of a mixture of beans having different seed coat color, shape and size, plant morphology

*Corresponding author: dahalbhishmaraj@gmail.com 
and yield potential. These genotypes are being used in several ways as dal (dry split pulses), dry bean, green pod vegetable, bean flour and a medicinal crop (Neuapne et al., 2004). In addition, they are used to make bread and Dhido (a typical Nepali food). Besides its uses as fodder and green manures, farmers also considered bean as a cash-generating crop (Neupane and Vaidya, 2002). Bean is an important source of dietary protein and starch in Africa and primary staple food in various parts of the Great Lakes (Hillocks et al., 2006). In Nepal, local landraces have been named as KBL (Karnali Bean Lines) and numbers are given as KBL-1, KBL-2 and they are grouped on the basis of their colors (ARS, 2011). The promising genotypes include KBL-3, PB0001, PB0002 and PB0048 (Bhujel et al., 2012).

Farmers of Jumla, Nepal are mostly growing bean in un-irrigated land and its successful establishment and yield depends on timely rainfall, particularly during germination, flowering and pod formation stages. Most of the farmers use harvested crop as a source of seed for next session crop without maintaining proper management and quality. Such seeds are not stored in appropriate environmental conditions and have low physical as well as genetic purity. These kinds of seeds are the reservoir of different seed borne diseases as well. As seed treatment is not popular, broadcasted seeds are attacked by several soil microbes, which drastically reduce seed quality, vigour and seed viability. In addition, there is no proper screening of lines of Jumli beans based on seed vigour. Under such circumstances, the crop establishment and subsequent yield is largely affected, which is one of the reasons behind low production of beans in Jumla, compared to national average (MoALD, 2017). Crop yield and resource use efficiency depend on successful plant establishment in the field (Rahman et al., 2011). To maintain the optimum plant population in the field the germination and seed vigour must be good (De Villalobos and Pelaez, 2001). But there are no relevant literatures describing about the germination and seed vigour of the indigenous beans of Nepal. Keeping these points in view, a study was conducted for comparative study of germination and seed vigour of different indigenous bean genotypes of Nepal.

\section{MATERIALS AND METHODS}

Varietal response of Jumli beans (Phaseolus vulgaris) to seed germination and seed vigour was conducted under High-Tech nursery, Shree Kalika Falful Nursery of Chandannath Municipality- 9, Jumla during February to March, 2018. Being organic district, farmers of Jumla apply only organic fertilizers and bio-pesticides. The samples of pureline seeds of beans were collected from Agriculture Research Station, Vijaynagar, Jumla and farmer seed was collected from bean growers around the bean block as identified by DADO (District Agriculture Development Office), Jumla. The experiment was conducted in completely randomized design (CRD). 


\section{Treatment Details}

A total of 6 treatments, replicated four times, were done i.e. 5 pure lines of bean seed and 1 farmer seed were used for testing.

\section{Seed sowing}

Seed was soaked in normal water overnight and sown in seedling tray using coco peats as growth media; in each treatment, 25 seeds were sown.

\section{Speed of germination}

Twenty-five seeds of each treatment in each replication were planted for germination. Number of seedlings emerging daily was counted from days of sowing the seeds till the time germination was completed or ceased. The days to germination/emergence of each replication was noted. Also, the speed of germination or emergence $(\mathrm{X})$ was computed by using the following formula given by Maguire (1962).

$\mathrm{X}=\frac{\text { numberofseedlingemerged }}{\text { daystofirstcount }}+\ldots \ldots+\frac{\text { increaseofseedlingsemergedfrompreviouscount }}{\text { daystof inalcount }}$

Higher the value of $X$, higher is the seed vigour.

\section{Germination percentage}

Germination percent of seeds for each replication was computed as:

Germination $\%=\frac{\text { Number of seeds germinated }}{\text { Numberofseedssown }}$

\section{Seed vigour index}

After the determination of Root and Shoot length, seed vigour index was determined using following formula mentioned below (Abdual-Baki and Andersen, 1973):

Vigour Index $=($ Mean of root length + mean of shoot length $) \times$ percentage of seed germination

\section{Days to true leaf emergence}

The days to true leaf emergence in over $50 \%$ of sample seedling observed was noted per replication of pure line; here true leaf was considered other than cotyledons leaf.

\section{Root and shoot length ratio}

Root shoot length ratio was determined slightly different from original root shoot ratio (i.e. root dry weight/ shoot dry weight). After 30 days the root and shoot length of bean seedling were measured. It was done with destructive simple random sampling. Around 10 seedlings were uprooted from each replication and root and shoot length of each seedlings were measured. Then the root shoot length ratio was computed by using formula:

Root Shoot length ratio $=\frac{\text { root lengt } h}{\text { shoot lengt } h}$ 


\section{Dry weight}

The sample was subjected to oven dry along with root for about 17 hours at $105^{\circ} \mathrm{C}$ and its biomass was determined by measuring the dry weight.

\section{Data analysis}

The data obtained from the experimental plots on various parameters were statistically analyzed. The obtained data were tabulated in Microsoft Excel and Gen Stat was used to analyze the data. Mean comparison, at 5\% level of significance, was done by using Duncan's Multiple Range Test (DMRT).

\section{RESULTS AND DISCUSSION}

The characters of indigenous bean genotype are presented in Table 1. KBL-3 and PB0001 genotypes had higher yield; but maturity days of KBL-3 is longer than PB0001. KBL-3, PB0001 and KBL-1 genotypes were resistant to anthracnose. KBL3, PB0002 and KBL-1 were trailing type while rest of the studied genotypes were busy.

Table 1. Characters of various indigenous bean genotypes

\begin{tabular}{|c|c|c|c|c|c|c|}
\hline Treatments & $\begin{array}{l}\text { Pure line } \\
\text { of beans }\end{array}$ & $\begin{array}{l}\text { Growth } \\
\text { habit }\end{array}$ & Yield & $\begin{array}{l}\text { Maturity } \\
\text { time(days) }\end{array}$ & $\begin{array}{l}\text { Seed } \\
\text { characters }\end{array}$ & Remarks \\
\hline $\mathrm{T} 1$ & KBL-3 & $\begin{array}{l}\text { Trailing } \\
\text { Type }\end{array}$ & $\begin{array}{l}2600- \\
2800 \mathrm{~kg} \mathrm{ha}^{-1}\end{array}$ & $105-115$ & $\begin{array}{l}\text { Elongated } \\
\text { and oval, } \\
\text { bluish black }\end{array}$ & $\begin{array}{l}\text { Resistance } \\
\text { to } \\
\text { anthracnose }\end{array}$ \\
\hline $\mathrm{T} 2$ & KBL-1 & $\begin{array}{l}\text { Trailing } \\
\text { Type }\end{array}$ & $\begin{array}{l}1800-2200 \\
\mathrm{~kg} \mathrm{ha}^{-1}\end{array}$ & $95-105$ & $\begin{array}{l}\text { Small, } \\
\text { circular, } \\
\text { pure black }\end{array}$ & $\begin{array}{l}\text { Resistance } \\
\text { to } \\
\text { anthracnose }\end{array}$ \\
\hline $\mathrm{T} 3$ & PB0002 & $\begin{array}{l}\text { Trailing } \\
\text { Type }\end{array}$ & & & $\begin{array}{l}\text { grayish with } \\
\text { black dots } \\
\text { or line }\end{array}$ & \\
\hline $\mathrm{T} 4$ & PB0001 & $\begin{array}{l}\text { Bushy } \\
\text { Type }\end{array}$ & $\begin{array}{l}2600- \\
2800 \mathrm{~kg} \mathrm{ha}^{-1}\end{array}$ & $100-105$ & $\begin{array}{l}\text { Elongated } \\
\text { and oval, } \\
\text { reddish with } \\
\text { white shade }\end{array}$ & $\begin{array}{l}\text { Resistance } \\
\text { to } \\
\text { anthracnose }\end{array}$ \\
\hline T5 & KBL-2 & $\begin{array}{l}\text { Trailing } \\
\text { Type }\end{array}$ & & & $\begin{array}{l}\text { Red with } \\
\text { shade of } \\
\text { other colors }\end{array}$ & \\
\hline T6 & $\begin{array}{l}\text { Farm- } \\
\text { saved } \\
\text { seeds } \\
(\text { KBL-3) }\end{array}$ & $\begin{array}{l}\text { Trailing } \\
\text { Type }\end{array}$ & & $105-115$ & $\begin{array}{l}\text { Elongated } \\
\text { and oval, } \\
\text { bluish black }\end{array}$ & $\begin{array}{l}\text { Resistance } \\
\text { to } \\
\text { anthracnose }\end{array}$ \\
\hline
\end{tabular}


Germination of various Jumli bean lines was shown in Table 2. Maximum germination percentage ( $96 \%$ ) was observed for variety KBL-3 followed by lines PB0002 (95\%) and PB0001 (93\%), while least germination percentage (69.00) was found for KBL-1 lines; the difference was statistically significant. Seed size is widely recognized measure of seed quality; large seeds have high seedling survival growth and establishment (Jerlin and Vadivelu, 2004). Higher germination percentage of lines PB0001, PB0002 and KBL-3 is probably due to its larger seed size. Hundred grain weight of different Jumli beans PB0001, PB0002, KBL-3, KBL -2 and KBL-1were found 43.3, 36, 27.4, 24.28 and 20.03g, respectively. Mut and Akay (2010) reported that, regardless of the other stress, larger seed exhibited $4 \%$ greater than smaller seeds of oat. Larger seed has higher water potential compared to small seed which results in higher germination percentage (Mut and Akay, 2010). Therefore, larger seeds perform better even under moisture stress condition. Similar findings were observed by Subba et al. (2016) and ARS Jumla (2017). Elevated and quicker germination in larger seed might be due to presence of higher amount of carbohydrate and other nutrients compared to small sized seeds (Gunaga et al., 2011; Ambika et al., 2014). Statistically significant result was obtained in speed of germination of Jumli bean genotypes; maximum speed of germination (1.763) was found for line KBL-3 which was statistically similar with line PB0002 (1.620). The least speed of germination (0.968) was found for KBL-1. Bean lines with larger seeds were found to have higher speed of germination, this is ascribed by the fact, larger seed have higher amount of carbohydrate and other nutrients (Gholami et al., 2009). Similar result was obtained in oat cultivars with different seed size (WIllenborg et al., 2005).

Table 2. Germination percentage and speed of germination of various Jumli bean lines

\begin{tabular}{lll}
\hline Treatments & Germination \% & Speed of Germination (seedling day $^{-1}$ ) \\
\hline KBL-3 & $96.00^{\mathrm{a}}$ & $1.763^{\mathrm{a}}$ \\
KBL-1 & $69.00^{\mathrm{d}}$ & $0.968^{\mathrm{c}}$ \\
PB0002 & $95.00^{\mathrm{a}}$ & $1.620^{\mathrm{a}}$ \\
PB0001 & $93.00^{\mathrm{a}}$ & $1.237^{\mathrm{b}}$ \\
KBL-2 & $86.00^{\mathrm{b}}$ & $1.420^{\mathrm{b}}$ \\
Farm-saved seeds & $80.00^{\mathrm{c}}$ & $1.235^{\mathrm{b}}$ \\
LSD $(0.05)$ & 5.098 & 0.184 \\
C.V. & $4.00 \%$ & $9.00 \%$ \\
\hline
\end{tabular}


Table 3. Seed vigour index, days to true leaf emergence, root-shoot ratio and dry weight of indigenous beans

\begin{tabular}{lllll}
\hline Treatments & $\begin{array}{l}\text { Seed Vigour } \\
\text { Index }\end{array}$ & $\begin{array}{l}\text { Days to true leaf } \\
\text { emergence }\end{array}$ & $\begin{array}{l}\text { Root Shoot } \\
\text { Ratio }\end{array}$ & $\begin{array}{l}\text { Dry weight } \\
(\mathrm{g})\end{array}$ \\
\hline KBL-3 & $1367^{\mathrm{a}}$ & $23.50^{\mathrm{a}}$ & $1.308^{\mathrm{a}}$ & $3.25^{\mathrm{a}}$ \\
KBL-1 & $947^{\mathrm{b}}$ & $24.75^{\mathrm{a}}$ & $1.530^{\mathrm{a}}$ & $3.00^{\mathrm{a}}$ \\
PB0002 & $1298^{\mathrm{a}}$ & $25.00^{\mathrm{a}}$ & $1.305^{\mathrm{a}}$ & $4.00^{\mathrm{a}}$ \\
PB0001 & $1331^{\mathrm{a}}$ & $27.00^{\mathrm{b}}$ & $1.370^{\mathrm{a}}$ & $4.00^{\mathrm{a}}$ \\
KBL-2 & $1240^{\mathrm{a}}$ & $29.00^{\mathrm{c}}$ & $1.345^{\mathrm{a}}$ & $2.75^{\mathrm{a}}$ \\
Farm-saved & $1000^{\mathrm{b}}$ & $30.25^{\mathrm{c}}$ & $1.422^{\mathrm{a}}$ & $3.00^{\mathrm{a}}$ \\
seeds & & & & \\
SEM $( \pm)$ & 66.1 & 0.629 & 0.0689 & 0.363 \\
LSD & $196.4^{* * *}$ & $1.869^{* * *}$ & $0.2048^{\mathrm{ns}}$ & $1.079^{\mathrm{ns}}$ \\
C.V $\%$ & $11.00 \%$ & $4.70 \%$ & $10 \%$ & $21.80 \%$ \\
Grand mean & 1197 & 26.58 & 1.308 & 3.33 \\
\hline
\end{tabular}

*** indicate statistically significant, while ns denote non-significant

The maximum seed vigour index (1367) was found for bean variety KBL-3 which was statistically similar with lines PB0001 (1331) and PB0002 (1298). The least seed vigour index (947) was found for KBL-1 (Table 3). Bean lines with larger seeds were found to have higher seed vigour index, might be due to presence of higher amount of reserve food materials (Gholami et al., 2009; Finch-Savage and Bassel 2015). Further, larger seeds higher have higher protein content, dehydrogenase and alpha-amylase acticity (Ambika et al., 2014). Similar positive co-relation between seed size and vigour was observed by Sulochanamma and Reddy (2007) and Cookson et al. (2001). The farm-saved seeds showed lower response to seed germination and vigour characteristics. The seed sample from untrained farmers found to have lower germination percentage and reduced seedling vigour (Haque et al., 2007). Reduced seed vigour of farm saved seeds could be due to lack of proper training for seed sorting, healthy seed selection, roughing, harvesting, drying, seed treatment and storage (Haque et al., 2007). Shorter day (23.50) for true leaf emergence was found for bean variety KBL-3 which was statistically similar with lines KBL-1 (24.75) and PB0002 (25.00). Delayed in true leaf emergence (30.25) was found for Farm-saved seed which was statistically similar with bean variety KBL-2 (29.00), similar result was observed by Maun and Zhang (1990) and Kadege and Lyimo (2015). The poor germination and crop seedling establishment is due to prevalence of various seed borne diseases (Kadege and Lyimo 2015). Though, there was no statistically significant difference was observed between root to shoot length of different lines of Jumli beans, maximum root-shoot ratio (1.530) was found for bean variety KBL-1 and the least for observed in PB0002 (1.305). High root-shoot ratio for large sized seed might be due to high 
investment in root tissues promotion, that reach deeper levels of substrate with more water and nutrients (Canadell and Zedler, 1995; Yang and Midmore, 2005; Cicek, 2007). Further, the seeds with higher root length performs better even under drought conditions (Mut and Akay, 2010). Maximum dry weight (4.00 g) of seedlings was found for bean lines PB0002 and PB0001 and least for KBL-2 (2.75), but the result was statistically non-significant. Similar finding was observed by Nik et al. (2011). Large seeded seedlings found to have 2-3 times more dry weight of seedlings than that from small seeds (Agboola, 1996; Cicek, 2007). Dry weight accumulation during initial stage of seedling in larger seed is primarily a result of mobilization of storage reserve from cotyledons (Pearson, 2002; Cicek, 2007; Delgado et al., 2008).

\section{CONCLUSION}

The bean line KBL-3 was found superior and more responsive to seed germination and vigour characteristics with highest seed germination percentage, speed of germination, seed vigour index and earliest days to true leaf emergence, thus it would be better to suggest bean growing farmers to select KBl-3 genotype for better crop establishment.

\section{REFERENCES}

Abdual-Baki, A. and Andersen, J. (1973). Realationship between decarboxilation of glutamatic acid and vigour in soyabean seed. Crop Science, 13(2): 222-226.

Agboola, D. (1996). The effect of seed size on germination and seedling growth of three tropical tree species. Jornal of Tropical Science, 9(1):44-51.

Ambika, S., Manonmani, V. and Somasundaram, G. (2014). Review on effect of seed size on seedling vigour and seed yield. Research Journal of Seed Science, 7(1):31-38.

ARS. (2011). Annual Research Report. Vijaynagar, Jumla, Nepal: Agriculture Research Station.

ARS Jumla. (2017). Annual Report 2073/74 (2016/17). Nepal Agriculture Research Council, Government of Nepal.

Bhujel, R.B., Pandey, B., Rana, C.B., Mahat, P.M. and Shrestha, L.L. (2012). Varietal Performance of Phaseolous bean in Jumla. Proceedings of the 4th $S A S-N$ Convention (Pp. 4-6). Vijaynagar, Jumla: Agriculture Research Station, NARC.

Canadell, J. and Zedler, P. (1995). Underground structures of woody plants in Mediterranean Ecosystem of Australia, California and Chile. In: M.T. Arroyo, P.H. Zedler, and M.D. Fox, Ecology and Biogeography of Mediterranean Ecosystems in Chile, California and Australia. Ecological Studies (analysis and synthesis.Book series Vol. 108:177-210. 
Cicek, E. (2007). Seed size effects on germination, survival and seedling growth of Castanea sativa Mill. Journal of Biological Sciences, 7(2):438-441.

Cookson, W.R., Rowarth, J.S. and Sedcole, J.R. (2001). Seed Vigour in perennial rye grass (Lolibum perenne): effect and cause. Seed Science and Technology, 29 (1):255-270.

Delgado, J. A., Serrano, J.M., Lopez, F. and Acosta, F.J. (2008). Seed size and seed germination in the mediterranean fire-prone shrub Cistusla danifer. Plant Ecology, 197(2):269-276.

De Villalobos, A.E. and Pelaez, D.V. (2001). Influences of temperature and water stress on germination and establishment of Prosopis caldenia Burk. Journal of Arid Environments, 49(2):321-328.

Finch-Savage, W. and Bassel, G. (2015). Seed vigour and crop establishment: extending performance beyond adaptation. Journal of Experimental Botony, 67 (3):567-591.

Gholami, A., Sharafi, A., Sharafi, S. and Ghasemi, S. (2009). Germination of different seed size of PInto bean cultivars as affected by salinity and drought stress. Journal of Food Agriculture and Environment, 7 (2):555-558.

Gunaga, R., Doddabassava and Vasudeva, R. (2011). Influence of seed size on germination and seedling growth in Mammea suriga. Karnataka Journal of Agriculrural Sciences, 24 (3):415-416.

Haque, A., Akon, M., Islam, M., Khalequzzaman, K. and Ali, M. (2007). Study of seed health, germination and seedling vigour of farmers produced rice seeds. international Journal of Sustainable Crop Production, 2 (5):34-39.

Hillocks, R., Smodata, J.C., Chirwa, R. and Msolla, S. (2006). Phaseolus bean improvement in Tanzania, 1959-2005. Euphytica colume, 150 (1):215-231.

Jerlin, R. and Vadivelu, K. (2004). Effects of fertilizer application in nursery for elite seedling production of Pungam (Pongamia pinnata L. Picrre). Tropical Agriculture Reserach and Extension, 7:69-71.

Kadege, E. and Lyimo, H.J.F. (2015). Prevalence and control of wheat (Triticum aestivum L.) seed borne fungi in farmer-saved seeds. Archives of Phytopathology and Plant Protection, 48(7):601-610.

Maguire, J. (1962). Speed of germination-aid in selection and evaluation for seedling emergence and vigour. Crop Science, 2:176-177.

Maun, M.A. and Zhang, J. (1990). Seed size variation and its effects on seedling growth in agropyron pasmmophilum. Botanical Gazette, 151 (1):106-113.

MoALD. (2017). Statistical information on Nepalese agriculture 2073/74. Kathmandu: Ministry of Agriculture and Livestock Development, Government of Nepal. 
Mut, Z. and Akay, H. (2010).Effect of seed size and drought stress on germination and seedling growth of naked oat (Avena sativa L.). Bulgarian Journal of Agricultural Science, 16(4):459-467.

Neuapne, R.K, Shrestha, R., Vaidya, M.L. and Bhattarai, E.M. (2004). Agromorphological characterization of common bean (Phaseolus vulgaris L) at jumla. Proceedings of second SAS- $N$ convention. Kathmandu: Nepal Agricultural Research Council. Pp. 174-177.

Neupane, R. and Vaidya, M. (2002). Proceeding of the first stakeholders meeting on development of improved production technology pf Phaseolous beans to hills of mid western Nepal, 22 June ARS, Jumla. NGLRP, Rampur.

Nik, M., Babaeian, M. and Tavassoli, A. (2011). Effects of seed size and genotype on germination characteristics and seed nutrient content of wheat. Scientific Research and Essays, 6 (9):2019-2025.

Pearson, T.R.H., Burslem, D.F.R.P., Mullins, C.E. and Dalling, J. W. (2002). Germination ecology of neotropical pioneers: interacting effects of environmental conditions and seed size. Ecology, 83(10):2798-2807.

Rahman, M., Hossain, M. and Bell, R.W. (2011). Plant density effects on growth, yield and yield components of two soybean varieties under equidistant planting arrangement. Asian Journal of Plant Sciences, 10(5):278-286.

Subba, S., Poudel, P.K. and Kharel, G.P. (2016). Study of phytochemicals present in Jumli simi and effect of cooking on them. Golden Gate Journel of Science and Technology. Pp.1-8

Sulochanamma, B.N. and Reddy, Y.T. (2007). Effect of seed size on growth and yield of rainfed groundnut. Legume Research, 30 (1):33-36.

WIllenborg, C., Wildeman, J., Miller, A., Rossanagel, B. and Shirtliffe, S. (2005). Oat germiantion characteristics differ among genotype, seed size and osmotic potential. Crop Science, 45 (5):2023-2029.

Yang, Z. and Midmore, D. (2005). Modeling plant resources allocation and growth partitioning in responses to environmental heterogeneity. Ecological Modelling, 181 (1):59-77 